\title{
Response of Some Bread Wheat Cultivars to Irrigation Water Quality
}

\author{
Khudhair Abbas Jaddoa ${ }^{1}$, Abdoun Hashim Alwan², Khalid Ali Hussein ${ }^{2}$ \\ ${ }^{1}$ Department of Field Crop Science, College of Agriculture, University of Baghdad, Baghdad, Iraq \\ ${ }^{2}$ Department of Biology, College of Science, University of Kerbala, Kerbala, Iraq
}

Email address:

Khdhayerjaddoa@yahoo.com (K. A. Jaddoa)

\section{To cite this article:}

Khudhair Abbas Jaddoa, Abdoun Hashim Alwan, Khalid Ali Hussein. Response of Some Bread Wheat Cultivars to Irrigation Water Quality. International Journal of Applied Agricultural Sciences. Vol. 3, No. 6, 2017, pp. 143-147. doi: 10.11648/j.ijaas.20170306.11

Received: September 25, 2017; Accepted: October 19, 2017; Published: November 8, 2017

\begin{abstract}
A field trial was conducted in a private farm at AL-Hur region, holy Kerbala governorate - Iraq during 2015-2016 growing season. Six bread wheat cultivars were grown, namely lpa-99 AL-Rasheed, Abu-Ghraib-3, AL-Fateh, AL-Hussein and Bohooth-22 and irrigated with three water qualities: fresh river water, drainage water and alternate irrigation (fresh river water and drainage water). The design was Randomized Complete Block Design (R.C.B. D) with three replicates. The objective was to investigate the effect of different irrigation water qualities on some tolerance and susceptibly criteria of these cultivars. Stress susceptibly index (SSI), stress tolerance index (STI), tolerance of cultivars: (TOI), yield index (YI) and yield stability index (YSI) were studied. Results indicated that AL-Hussein cultivar gave the highest values of grain yield (680.00, 655.00 and $569.33 \mathrm{~g} \mathrm{~m}^{-2}$ ) under fresh river water, alternate water and drainage water compared with the lowest values of ALRashid cultivar $\left(527.33,511.00\right.$ and $\left.374.66 \mathrm{~g} \mathrm{~m}^{-2}\right)$, respectively. The reduction of grain yield $\left(\mathrm{g} \mathrm{m}^{-2}\right)$ of AL Hussein was the lowest 16.28\% compared with 35.64, 34.64, 33.00, 29.00 and 24.99\% for Bohooth-22, Abu-Ghraib -3, AL-Fateh, AL-Rasheed and lpa-99, respectively. This means that AL-Hussain cultivar was the most tolerant to the salinity of irrigation water where it possessed the highest value 1.196 of stress tolerant index (STI) and the lowest value 0.094 of stress susceptibility index (STI) compared with other cultivars. The drainage water gave the lowest values of grain yield $429.33 \mathrm{~g} \mathrm{~m}^{-2}$ compared with $601.22 \mathrm{~g}$ $\mathrm{m}^{-2}$ in fresh river water and the alternate water was in between $556.00 \mathrm{~g} \mathrm{~m}^{-2}$. It can be concluded, that a tolerant cultivar should be grown when salinized irrigation water is practiced.
\end{abstract}

Keywords: Bread Wheat, Water Quality, Stress Tolerance Index (STI), Stress Susceptibility Index (SSI), Yield Stability Index (YSI), Wheat Cultivars

\section{Introduction}

Irrigation water is considered the first limiting factor which affects all aspects of growth and productivity [1]. Scarcity of water for agricultural uses is one of the major problems facing many countries in the world with the expectation this problem will continue in the future [2]. Therefore, great efforts will be needed to find out another resource of water for crop irrigation e.g. wells water, drainage water and even sewage water after its treatment [3]. However, these, water qualities might adversely affect by time the crop production and chemical and physical properties of soil. Iraq is among many countries which facing a shortage of water, in particular, for agricultural purposes, due to the establishing new dams and agricultural projects on Tigris and Euphrates by Turkey and Syria and the declining of rainfall recently.

Wheat plants are classified as moderate tolerant to the salinity $[4,5]$. For reasonable yield, selection of high yield, efficient cultivars and tolerant to the salinity is needed, especially when grown by using wells and drainages water with high salinity level [6]. For efficient use of salinized water, a tolerant cultivar must be grown to achieve an acceptable grain yield with soil characteristics been maintained without deterioration. One of the approaches to avoid soil properties deterioration is using the alternate irrigation (i. e. Irrigation with fresh water and then drainage water and growing tolerant cultivars [7]. As this approach is rarely practiced in Iraq, the present study was conducted to 
investigate the effect of different irrigation water qualities on some bread wheat cultivars to find out the most tolerant one under such conditions.

\section{Materials and Methods}

\subsection{Experimental Site and Details}

A field experiment was carried-out in a private farm at AL-Hur region - Kerbala governorate, Iraq during 20152016 growing season. The objective was to investigate the response of six bread wheat cultivars (lpa-99, ALRasheed, Abu-Ghraib-3, AL-Fateh, AL-Hussein, and Bohooth-22) to the different qualities of water irrigation. Six cultivars were grown on 15 Nov. 2015. The design was randomized complete block design (R.C.B.D) with three replicates. The dimension of each plot was $2 \times 2.5 \mathrm{~m}$ with $0.5 \mathrm{~m}$ left between plots and $1 \mathrm{~m}$ between replicates. The seeding rate was $100 \mathrm{~kg}$ ha- 1 . The fertilizer regime was $400 \mathrm{~kg}$ ha-1 of N: P $(27: 27: 0)$ applied once at the seed bed preparation and $100 \mathrm{~kg} \mathrm{~N}$ ha-1 applied evenly at the tillering and booting stages. The first irrigation was by using fresh river water $(2.0 \mathrm{ds} \mathrm{m}-1)$ for all plots (i.e. germination irrigation). At the full emergence of seedlings, irrigation water treatments were imposed. They were (fresh river water, drainage water and alternate water (fresh + drainage).

\subsection{Studied Characters}

\subsubsection{Grain Yield $\left(\mathrm{g} \mathrm{m}^{-2}\right)$}

It was calculated by harvesting all plants in 1 squared meter area for each plot.

\subsubsection{Stress Susceptibility Index (SSI)}

This was calculated by using the following equation [8]:

$$
\mathrm{SSI}=\left[1-\mathrm{Ys}_{\mathrm{s}} / \mathrm{Yp}\right] /\left[1-\overline{\mathrm{Y}}_{\mathrm{s}} / \overline{\mathrm{Y}} \mathrm{p}\right]
$$

Where

SSI = Index of the cultivar susceptibility to the water quality

Ys $=$ weight of grain yield $\left(\mathrm{g} \mathrm{m}^{-2}\right)$ of

cultivar under stress

$\mathrm{Yp}=$ weight of grain yield $\left(\mathrm{g} \mathrm{m}^{-2}\right)$ of cultivar under normal condition (i.e. fresh water irrigation).
$\bar{Y}_{s}=$ grain yield of cultivar $\left(\mathrm{g} \mathrm{m}^{-2}\right)$ under stress

$\bar{Y} \mathrm{p}=$ grain yield of cultivars $\left(\mathrm{g} \mathrm{m}^{-2}\right)$ under normal conditions (i.e. fresh water irrigation).

\subsubsection{Stress Tolerance Index (STI)}

It was calculated by using the following equation [9]:

$$
\mathrm{STI}=\mathrm{Ys} \times \mathrm{Yp} / \mathrm{Y} 2 \mathrm{p}
$$

\subsubsection{Tolerance of Cultivar (TOL)}

It was calculated according to the equation of [10]:

$$
\mathrm{TOL}=\mathrm{Yp}-\mathrm{Ys}
$$

\subsubsection{Yield Index (Yl)}

This was calculated according to the equation of [11]:

$$
\mathrm{Yi}=\mathrm{Ys} / \overline{\mathrm{Y}} \mathrm{s}
$$

\subsubsection{Yield Stability Index (YSI)}

This was calculated by using the equation of [12]:

$$
\mathrm{YSI}=\mathrm{Ys} / \mathrm{Yp}
$$

\section{Results and Discussion}

\subsection{Grain Yield $\left(\mathrm{g} \mathrm{m}^{-2}\right)$}

Table (1) shows the effect of variety and water quality on grain yield $\left(\mathrm{g} \mathrm{m}^{-2}\right)$. It is clear that $\mathrm{AL}-$ Hussein cultivar significantly gave the highest grain yield $634.77 \mathrm{~g} \mathrm{~m}^{-2}$ compared with lowest yield $471.00 \mathrm{~g}$. $\mathrm{m}^{-2}$ for AL- Rasheed cultivar. For water quality, fresh river water achieved the highest grain yield $601.22 \mathrm{~g} \mathrm{~m}^{-2}$ compared with the lowest value $429.33 \mathrm{~g} \mathrm{~m}^{-2}$ for drainage water. It is also clear from Table (1) that AL-Hussein cultivar gave the highest values of grain yield $680.00,655.00$ and 569.33 g. $\mathrm{m}^{-2}$ under fresh water, alternate water and drainage water compared with the lowest values 527.33, 511.00 and 374.66 g. $\mathrm{m}^{-2}$ for AL-Rasheed cultivar, respectively. This means that the reduction of grain yield in AL- Hussein cultivar following drainage water was the lowest $16.28 \%$ compared with the highest percentage of

\begin{tabular}{|c|c|c|c|c|c|c|c|}
\hline Water quality Variety & Ipa-99 & AL-Rasheed & Abu ghraib & AL-Fath & AL-Hussein & Bohooth 22 & $\begin{array}{l}\text { Average of } \\
\text { Water quality }\end{array}$ \\
\hline Fresh river water & 582.66 & 527.33 & 633.33 & 589.00 & 680.00 & 595.00 & 601.22 \\
\hline Alternate water & 571.00 & 511.00 & 574.00 & 505.00 & 655.00 & 520.00 & 556.00 \\
\hline Drainage water & 440.00 & 374.66 & 414.00 & 395.00 & 569.33 & 383.00 & 429.33 \\
\hline Average of variety & 531.22 & 471.00 & 540.44 & 496.33 & 634.77 & 499.33 & \\
\hline L. S. D at 0.05 & \multicolumn{7}{|c|}{ Variety $=20.76$ water quality $=14.68$ Interaction $=35.96$} \\
\hline
\end{tabular}
reduction $35.64 \%$ for Bohooth-22 cultivar followed by 34.64 , $33.00,29.00$ and $24.49 \%$ reduction for Abu-Ghrab3, ALFateh, AL-Rasheed and Ipa-99, respectively.

Table 1. Effect of variety and water quality on Grain Yield $\left(\mathrm{g} \mathrm{m}^{-2}\right)$.

These results could be attributed to the lowest stress susceptibility index (SSI) 0.094 (Table 2), the highest value of stress tolerance index (STI) 1.196 (Table 3) and the highest value of yield stability index (YSI) 1.047 (Table 6) for AL- Hussein cultivar, respectively compared with other cultivars. These results were in agreement with the findings Of [13] when AL-Hussein cultivar possessed the highest values of STI 0.887 compared with 0.589 for AL-Rasheed 
cultivar and the lowest value $29.884 \%$ of membrane injury compared with $35.074 \%$ for AL-Rasheed cultivar.

\subsection{Stress Susceptibility Index (STI)}

Table (2) also shows that when plants irrigated with the drainage water. AL- Hussein gave the lowest value of SSI 0.241 compared with the highest value 0.356 for Bohooth, respectively. This suggests that AL-Hussein was the less susceptible variety to the salinity and Bohooth was the most susceptible. These results were supported by the findings of [13] when AL-Hussein was the most tolerant variety to the salinity in their study due to its high stress tolerance index (STI) and high chlorophyll stability.

Table 2. Effect of variety and water quality on Stress susceptibility index.

\begin{tabular}{|c|c|c|c|c|c|c|c|}
\hline $\begin{array}{ll}\text { Water quality } & \text { Variety } \\
\end{array}$ & Ipa-99 & AL-Rasheed & Abu ghraib & AL-Fateh & AL-Hussein & Bohooth 22 & $\begin{array}{l}\text { Average of } \\
\text { Water quality }\end{array}$ \\
\hline Fresh river water & 0.000 & 0.000 & 1.000 & 0.000 & 0.000 & 0.000 & 0.000 \\
\hline Alternate water & 0.025 & 0.084 & 0.043 & 0.141 & 0.042 & 0.126 & 0.077 \\
\hline Drainage water & 0.245 & 0.254 & 0.311 & 0.325 & 0.241 & 0.356 & 0.289 \\
\hline Average of variety & 0.090 & 0.113 & 0.118 & 0.155 & 0.094 & 0.161 & \\
\hline L. S. D at 0.05 & \multicolumn{7}{|c|}{ Variety $=0.025$ water quality $=0.018$ Interaction 0.044} \\
\hline
\end{tabular}

\subsection{Stress Tolerant Index (STI)}

Table 3 illustrates the effect of variety and quality on stress tolerance index (STI). It is clear that AL-Hussein gave the highest value 1.196 of STI compared with the lowest one 0.693 for AL-Rasheed variety. For water quality, irrigation with the drainage water gave the lowest value 0.718 compared with 0.940 and 1.007 for alternate and fresh river water, respectively. This table also shows that AL-Hussein gave the highest values of STI 1.028 and 1.255 when irrigated with drainage and alternate water, the lowest values were 0.550 and 0.755 for AL-Rasheed, respectively. In a study of [13], same findings were achieved when AL-Hussein was more tolerant than AL-Rashid. This finding confirmed than AL-Hussein variety possess tolerance mechanism better discarding $\mathrm{Na}^{+}$and $\mathrm{cl}^{-}$ions from the vegetative parts.

Table 3. Effect of variety and water quality on Stress tolerance index.

\begin{tabular}{|c|c|c|c|c|c|c|c|}
\hline Water quality & Ipa-99 & AL-Rasheed & Abu ghraib & AL-Fateh & AL-Hussein & Bohooth 22 & $\begin{array}{l}\text { Average of } \\
\text { Water quality }\end{array}$ \\
\hline Fresh river water & 0.969 & 0.775 & 1.016 & 0.98 & 1.305 & 0.999 & 1.007 \\
\hline Alternate water & 0.944 & 0.755 & 0.972 & 0.84 & 1.255 & 0.873 & 0.94 \\
\hline Drainage water & 0.727 & 0.55 & 0.703 & 0.656 & 1.028 & 0.643 & 0.718 \\
\hline Average of variety & 0.88 & 0.693 & 0.897 & 0.826 & 1.196 & 0.838 & \\
\hline L.S.D at 0.05 & \multicolumn{7}{|c|}{ Variety $=0.003$ water quality $=0.002$ Interaction 0.006} \\
\hline
\end{tabular}

\subsection{Tolerance of Varieties (TOL)}

Table 4 indicates the effect of variety and water quality on the tolerance (TOL) of varieties. The less the differences in grain yield between fresh river and drainage water methods, the more tolerance the variety. Based on this fact. It is clear that AL-Hussein gave the lowest differences 45.23 followed by 51.4456 .3392 .6692 .88 and 95.66 for 1 pa-99, ALRasheed, AL-Fateh, and Abu-Ghraid-3, respectively.

Table 4. Effect of variety and water quality on Tolerance.

\begin{tabular}{|c|c|c|c|c|c|c|c|}
\hline Water quality & Ipa-99 & AL-Rasheed & Abu ghraib & AL-Fateh & AL-Hussein & Bohooth 22 & $\begin{array}{l}\text { Average of } \\
\text { Water quality }\end{array}$ \\
\hline Fresh river water & 0.00 & 0.00 & 0.00 & 0.00 & 0.00 & 0.00 & 0.00 \\
\hline Alternate water & 11.66 & 16.33 & 59.33 & 84.00 & 25.00 & 75.00 & 45.22 \\
\hline Drainage water & 142.66 & 152.67 & 219.33 & 194.00 & 110.70 & 212.00 & 171.89 \\
\hline \multirow[t]{2}{*}{ Average of variety } & 51.44 & 56.33 & 92.88 & 92.66 & 45.23 & 95.66 & \\
\hline & \multicolumn{7}{|c|}{ Variety $=7.250$ water quality $=5.131$ Interaction $=13.421$} \\
\hline
\end{tabular}

For water quality, the alternate water method gave the lowest value 45.22 compared with 171.89 for drainage water. It is also clear from table (4) that AL-Hussein gave the lowest value 110.70 when irrigated with drainage water compared with 212.00 and 219.33 for Bohooth 22 and Abu-Ghraib-3 with significant differences between them, respectively. In the light of these results in table (4), AL-Hussein was the most tolerant variety to the salinity and Abu-Ghraib-3 and Bohooth-22 were the most susceptible ones. The performance of AL-Hussein variety as the most tolerant one could be attributed to its lowest stress susceptibility index (Table2) highest value of stress tolerance index (Table 3) and highest value of yield stability index (Table 6) compared with other varieties. In fact, [13], found that AL-Hussein had its own mechanism in discarding and/or avoiding $\mathrm{Na}$ from active sites and keeping high concentration to $\mathrm{K}$ maintain metabolic processes and synthesis of dry matter during different growth stages 


\subsection{Yield Index (YI)}

It is clear from Table 5, that Al-Hussein variety gave the highest value 1.212 of yield index compared with the lowest one 0.866 for Bohooth. Also, it was found that Al-Hussein achieved the highest values of yield index under all irrigation water quality1.142, 1.178 and 1.316 , respectively. This was due to the highest values of yield stability index of Al-Hussein $1.142,1.100$ and 0.900 under all irrigation water treatment, respectively. (Table 6). Table 5 also showed that water quality treatment, had no significant effect on this character.

Table 5. Effect of variety and water quality on Yield Index.

\begin{tabular}{|c|c|c|c|c|c|c|c|}
\hline Water quality & Ipa-99 & AL-Rasheed & Abu ghraib & AL-Fateh & AL-Hussein & Bohooth 22 & $\begin{array}{l}\text { Average of } \\
\text { Water quality }\end{array}$ \\
\hline Fresh river water & 0.984 & 0.880 & 1.008 & 0.989 & 1.142 & 0.699 & 0.950 \\
\hline Alternate water & 1.023 & 0.919 & 1.032 & 0.908 & 1.178 & 0.956 & 1.003 \\
\hline Average of variety & 1.029 & 0.907 & 1.019 & 0.956 & 1.212 & 0.866 & \\
\hline L.S.D at. 0.05 & Variety & ater quality $=0$. & Interaction $=0$ & & & & \\
\hline
\end{tabular}

\subsection{Yield Stability Index (YSI)}

Table (6) illustrates the effect of variety and water quality on yield stability index. It is clear that AL-Hussein gave the highest value 1.047 of YSI compared with 0.788 for ALRasheed variety. Moreover, AL-Hussein obtained the highest value 0.900 when irrigated with drainage water compared with lowest one 0.630 for AL-Rasheed variety. This result parallels with the highest value 1.316 of yield index for ALHussein and the lowest 0.921 for AL-Rashid when irrigated with drainage water (Table 5). This finding confirmed that, AL-Hussein variety possess tolerance mechanisms better than AL-Rasheed where the tolerance was highly correlated with discarding $\mathrm{Na}^{+}$and $\mathrm{Cl}^{-}$ions from the vegetative parts (13). Among these mechanisms, the high chlorophyll stability index. In fact, [13], found that AL-Hussein achieved 0.838 compared with 0.727 for AL-Rasheed variety under salinity stress with $\mathrm{NaCl}$. The stability of chlorophyll is considered as an indicator for plant tolerance, therefore, the abundance of chlorophyll in the plant leaves is leading to an increase in the photosynthesis rate and consequently a high dry matter is produced. All these give evidence for the salt tolerance by plants [14]. Table (6), also, shows that the drainage water gave the lowest value 0.711 of yield stability index compared with 0.933 and 1.000 for alternate and fresh river water, respectively.

Table 6. Effect of variety and water quality on yield stability index.

\begin{tabular}{|c|c|c|c|c|c|c|c|}
\hline Water quality & Ipa-99 & AL-Rasheed & Abu ghraib & AL-Fateh & AL-Hussein & Bohooth 22 & $\begin{array}{l}\text { Average of } \\
\text { Water quality }\end{array}$ \\
\hline Fresh river water & 0.983 & 0.88 & 1.008 & 0.986 & 1.142 & 0.999 & 1.000 \\
\hline Alternate water & 0.958 & 0.855 & 0.964 & 0.848 & 1.100 & 0.873 & 0.933 \\
\hline Average of variety & 0.892 & 0.788 & 0.889 & 0.832 & 1.047 & 0.838 & \\
\hline L.S.D at. 0.05 & \multicolumn{7}{|c|}{ Variety $=0.004$ water quality $=0.003$ Interaction $=0.007$} \\
\hline
\end{tabular}

\section{Conclusions}

It can be concluded, that AL-Hussein variety was the most tolerant variety to the salinized irrigation water whether irrigated by alternate or drainage water as it possessed the highest values of stress tolerance index (STI) and yield ++++ index(YI). Varieties had the lowest values of these two criteria (STI and YI) were considered as most susceptible ones.

\section{References}

[1] Almeselmani, M., Abdullah, F., Hareri, F., Naaesan, M., Ammar, M. A., Kanbar, O. Z., and Saud, Abd. (2011). Effect of drought on different physiological characters and yield component in different Syrian durum wheat varieties. J. Agric. Sci., 3: 127-133.

[2] FAO. (2013). The State of Food Insecurity in the World 2013: Economic growth is necessary but not sufficient to accelerate reduction of hunger and malnutrition. Rome, FAO.

[3] Miyamoto, S., Riley, T. Gobran, G. and Petticrew, J. (1986).
Effects of saline water irrigation on soil salinity, pecan tree growth and nut production. Irrig. Sci., 7:83-95.

[4] Maas, E. V. (1986). Salt tolerance of plants. Applied Agricultural Research 1: 12-26.

[5] Esfandiari, E., Shekari, F., Shekari, F. and Esfandiari, M. (2007). The effect of salt stress on antioxidant enzymes activity and Lipid peroxidation on the Wheat seedling. Notulae Botanicae Horti Agrobotanici Cluj-Napoca, 35 (1):48-56.

[6] Moaveni, P. (2011). Effect of water deficit stress on some physiological traits of wheat (Triticum aestivum). Agricul. Sci. Res. J., 1: 64 - 68.

[7] Francois, L. E. (1994). Yield and quality response of saltstressed garlic. Hort. Science, 29:1314-1317.

[8] Fischer, R. A. and Maurer, R. (1978). Drought resistance in spring wheat cultivars. I. Grain yield response. Aust. J. Agric. Res., 29:897- 907.

[9] Fernandez, G. C. J. (1992). Effective selection criteria for assessing plant stress tolerance. In: proc, of the Int. Symp. On adaptation of vegetables and other food crops in temperature and water stress. Tqiwan: 257-270. 
[10] Hossain, A. B., Sears, A. G., Cox, T. S. and Paulsen, G. M. (1990). Desiccation tolerance and its relationship to assimilate partitioning in winter wheat. Crop Sci., 30:622-627.

[11] Gavuzzi, P., Rizza, F., Palumbo, M., Campaline, R. G., Ricciardi, G. L. and Borghi, B. (1997). Evaluation of field and laboratory predictors of drought and heat tolerance in winter cereals. Plant Sci., 77:523-531.

[12] Bouslama, M. and Schapaugh, W. T. (1984). Stress tolerance in soybean. Part 1: evaluation of three screening techniques for heat and drought tolerance. Crop Sci., 24:933-937.
[13] Abdoun H. Alwan, Khalid A. Hussein and Khudhair A. Jaddoa. (2015). Effect of chloride on response of two Wheat cultivars (Triticum aestivum L.) at germination and early seedling stages. International Journal of Applied Agricultural Sciences, 1 (3): 60-65.

[14] Mohan, M. M., Lakshmi, S. N., Ibrahim, S. A. (2000). Chlorophyll stability Index (CTI): its impact on salt tolerance in rice. IRRI news letter, 38-39 pp. 